\title{
The use of reverse logistics for waste management in a Brazilian grocery retailer
}

Waste Management \& Research

2016, Vol. 34(1) 22-29

(C) The Author(s) 2015

Reprints and permissions:

sagepub.co.uk/journalsPermissions.nav DOI: 10.1177/0734242X15615696

wmr.sagepub.com

@SAGE

Karina TS Dias and Sergio S Braga Junior

\begin{abstract}
Retail growth is a result of the diversification of departments with the intention to look to consumer's needs and level of demand. Pressed by consumers and by the law, the adoption of environmental preservation practices is becoming stronger among grocery retailers. The objective of this research was to analyse the practices of reverse logistics performed by a retailer and measure the amount of waste generated by each department. To reach the proposed goal, a field research study was conducted to directly observe a grocery retailer in the state of Sao Paulo, Brazil, for a period of 6 months and monitor the amounts of cardboard and plastic discarded by each department. Using the Wuppertal method, the first result observed was that the retailer stopped its monthly production of approximately 20 tonne of biotic and abiotic material, which influence global warming and degradation of the ozone layer. Another result observed with the implementation of reverse logistics, was that the general grocery department mostly used cardboard and plastic. This sector includes products such as food cupboard, drinks, household, health and beauty, and pet articles. The fresh fruit and vegetable department and the meat, chicken and frozen department were increasingly using less plastic and cardboard packaging, increasing the use of returnable and durable packaging and thus promoting sustainability.
\end{abstract}

\section{Keywords}

Reverse logistics, waste management, retail, recycling, sustainability, solid waste

\section{Introduction}

Environmental preservation is a frequent theme in the current business scenario. Companies' awareness toward the conservation of natural resources involves more than the possibility of branding and customer loyalty. Environmental sensitivity is present in several countries, and in Germany and the Netherlands, this perception by the agents (companies and individuals) is quite high. In other countries, such as the United States, the largest force linked to reverse logistics is associated with the potential value that can be recovered from the reuse of products, parts, or recycled materials (Kokkinaki et al., 2001).

In this context, retailers have begun to take on new tasks, such as the commitment to reduce the waste they generate, and to recycle and reuse what is generated, with the purpose of increasing their responsibility to the final consumer (Braga Junior and Rizzo, 2010). One method is to adopt the practice of reverse logistics, which is recognised as the area of business logistics that plans, operates, and controls the flow of materials corresponding to the return of after-sales and post-consumer.

The production cycle, through reverse distribution channels, adds values of different natures: economic, ecological, lawful, logistical, and related to corporate image, among others (Leite, 2003). This care for the environment is owing to the fact that incorrect disposal of waste strongly affects the environment. Currently, supermarket retailers are paying more attention to the practice of reverse logistics because of great public concern for the environment as well as the influence of laws, such as the Brazilian National
Policy on Solid Waste (NPSW). The use of reverse logistics allows the recycling of packing used by retailers, ensuring the return of these materials to the production process, and reducing their environmental impact. Thus, the problem of research that guides the present study may be expressed by the following question: How do reverse logistics practices deployed by a supermarket, in the region of Alta Paulista, contribute to sustainability? In this sense, the objective of the research was to analyse the reverse logistics practices carried out by a supermarket and quantify the volume of waste generated by each department.

As a result of this study, it was observed that the supermarket stopped generating $20 \mathrm{t}$ of biotic and abiotic materials per month (using the Wuppertal method), and these materials are influencers on global warming and the depletion of the ozone layer. Another result observed with the implementation of reverse logistics was that the grocery department uses the most cardboard and plastic packaging, and that the fresh fruits and vegetables departments and meat departments are increasingly using less plastic packaging and cardboard, and increasing the use of returnable and durable packaging, thus promoting sustainability.

Unesp - Univ. Estadual Paulista, Tupã, São Paulo, Brazil

\section{Corresponding author:}

Sergio Silva Braga Junior, Unesp - Univ. Estadual Paulista, Rua Domingos da Costa Lopes,780, Tupã, São Paulo 17602496, Brazil. Email: sergiodatupa.unesp.br 


\section{Grocery retail}

Retail is a part of the distribution channel and the main intermediary between industry and the final consumer. Thus, it can be defined as 'all activities which include the process of selling products and services a personal need of the final consumer' (Parente, 2000: 22). Historically, retail originated from informal sales taking place on city streets, and evolved into stores and emporiums that sold durable and non-durable products. Since the Industrial Revolution, with the growth of industry and the creation of standardised products, commercial establishments have grown, resulting in large self-service markets (Senhoras, 2003).

For Dias (2003), retail is divided into selling of general goods and selling of services, and the supermarkets are inserted in the food retailing category.

Some authors, such as Parente (2000), Saab and Gimenez (2000), Dias (2003), and Levy and Weitz (2000), classified grocery retails as self-service systems relying on a variety of between 4000 and 14,000 products, including food and non-food items, with at least two checkouts and a sales floor area of between $300 \mathrm{~m}^{2}$ and $5000 \mathrm{~m}^{2}$ Braga Junior et al., (2009). Supermarkets consist of sections, such as grocery, butcher, cleaning products, etc., and provide carts and baskets to consumers, without requiring the presence of a seller. Another important feature of this sector is high turnover of products with low profit margins (Saab and Gimenez, 2000).

Over time, grocery retail has undergone several changes. According to Parente and Gelman (2006), these changes have occurred mainly because of the influence of society, which is increasingly aware of the scarcity of natural resources. Thus, the protection of the environment shall be the object of attention in companies operating in retail after a socially responsible position. Retailers are now assuming a new role; committing to the reduction of waste generation, recycling, and reuse; and creating the effect of increasing their responsibility to the final consumer (Braga Junior and Rizzo, 2010).

Among the environmentally correct actions, carried out by companies in the grocery retail segment, are the use of recyclable packaging, encouragement of the practice of selective waste collection, and prevention of wasting natural resources such as water and electricity (Parente and Gelman, 2006).

In fact, grocery retails are increasing their accountability to the consumer's concern for the environment. Companies that adopt environmentally friendly practices are recognised by the consumer, thus creating a competitive advantage in the marketplace. Another result of these actions for retailers that operate in the supermarket area, is increased business profitability, which generates economic benefits.

\section{Recycling and solid waste reuse}

Since the Industrial Revolution large-scale production has made the volume and diversity of waste generated in urban areas increase; humans are experiencing the era of disposability (Fehr, 2014). Most products are used and then thrown away or incinerated causing considerable damage to the environment. Currently, more stringent laws and growing consumer awareness are driving companies to think about their responsibility for their products after use (Veiga, 2013).

Parente and Gelman (2006) considered companies to be open systems that constantly interact with the environment where they are inserted and make terms of trade accordingly. Thus, the survival of enterprises is dependent on a healthy environment, because when the environment comes into degradation, the system is compromised.

Recycling is defined as returning waste materials to the processing line in order to reduce process costs and open up new possibilities (Braga Junior and Rizzo, 2010; Chaves et al., 2014; Veiga, 2013). According to Motta (2011: 9-10), the word recycling was introduced to the international vocabulary when it was found that the sources of oil and other non-renewable raw materials were (and are) running out. To this author, recycling is a reverse channel revaluation, where materials discarded from post-consumer products are extracted industrially, turned into secondary raw materials, not directly taken from nature or recycled, and are then incorporated into the manufacture of new products. Recycling saves energy and natural resources, bringing materials that were thrown out or discarded back to the productive cycle.

For Mano et al. (2005) the potential benefits of recycling include: (a) 'Reduction in the consumption of non-renewable natural resources, when replaced by recycled waste'; (b) 'Reduction of consumption of the virgin material for production process'; (c) 'Reduction of pollution' (John, 2000), and (d) 'Reduction of areas required to landfill as waste is used again as consumer goods' (Pinto, 1999).

The recycling and reuse of materials that would be discarded, and the remains that arise over the activities of the grocery retail, create a reverse flow (Braga Junior et al., 2009). The reverse flow of goods that were not consumed becomes an important tool for the sustainability of organisations (Braga Junior and Rizzo, 2010).

Authors, such as Gonçalves (2003) and Mano et al. (2005) explained that reducing the generation of waste, instead of reusing, and recycling these materials, are parts of the clean production targets and cleaner production processes initially employed by the industry and today have been adopted by various business sectors.

To meet the demands imposed by the NPSW, Law No. $12,305 / 2010$, increased investment in technology, education, and knowledge management is needed. According to Nonaka and Takeuchi (1997, as cited in Marchi, 2011), it is of great importance to generate beliefs, commitments, situations, and appropriate interactions so that information is converted into knowledge and can enhance behaviours and attitudes. The NPSW sets standards requiring major market players to provide a suitable destination for solid waste that is generated in the manufacturing process and after consumption of various goods. Thus, one must have a means that enables the return of products and postconsumer packaging for the industry to adopt the processes and the most suitable procedures to recover waste components with the lowest environmental impact. In this sense, Dowlatshahi 
(2000) explained that reverse logistics can be a tool in waste management because it is a process in which the manufacturer receives the waste generated after the consumption of products and may thus recycle, remanufacture, or dispose of.

\section{Reverse logistics}

\section{Definition and function of the reverse logistics}

Braga Junior and Santos (2015) analysed reverse logistics in the supermarket sector and suggested it is made up of three main elements: industry; retail, and the secondary market (represented by the recycling companies). These elements interact with each other, making transfer operations of materials that return to the supply chain through the secondary market, which returns these materials, many times, in the form of new packing ready to be used again by the industry. So, the reverse flow originates from the retailer, which transfers the packings to the secondary market, which, in turn, sells the recycled material to industry, thus restarting the cycle. Over time, the reverse logistics concept has had some modifications. However, one of the main explanations is given by Rogers and Tibben-Lembke (1999), who pointed that reverse logistics encompasses all of the logistical procedures of a company, but in the opposite direction, belonging only to the two concepts of recycling and removal of waste and the administration of returns.

Reverse logistics has been recognised as the area of business logistics that is used to plan, operate, and control the flow and logistic information corresponding to the return of after-sales and post-consumer goods to the production cycle through reverse distribution channels, which adds value of various kinds, such as economic, ecological, legal aspects, logistic, and related to corporate image, among others (Leite, 2003). The concept also gets a new feature, the part of strategic planning that should be treated as an independent activity, turning the business's attention to management of individual logistics (Daher et al., 2006). Horvath et al. (2005) stated that reverse logistics is not optional but mandatory. Nevertheless, many companies still do not deploy such processes because of difficulties or even disinterest (Daher et al., 2006).

For the implementation of reverse logistics to be efficient and generate expected returns, Ahluwalia and Nema (2006) stated that a company must first develop strong reverse logistics strategies and then clearly outline the financial, corporate, marketing, and other goals. Daher et al. (2006) presented the main factors that lead organisations to engage in reverse logistics, which are compiled by a group of researchers from universities worldwide in a database known as RevLog: (a) environmental laws; (b) economic benefits obtained; and (c) growing environmental awareness of consumers. In addition to these, Rogers and Tibben-Lembke (1999) also pointed to other reasons: (a) competitive reasons; (b) cleaning of the distribution channel; (c) profit margin of protection; and (d) value and asset recovery. Ahluwalia and Nema (2006) also described reverse logistics as other businesses with goals, objectives, information technology resources, individual and specific personnel, and responsible for the execution and development of the business.

For authors such as Hazen et al. (2014) and Bernon et al. (2001), reverse logistics is also recognised as a key issue in the context of management of the supply chain, leading to gaining a competitive advantage in the marketplace. Internationally, Kokkinaki et al. (2001) described reverse logistics as a factor that has become popular over the years owing to a constantly growing environmental sensitivity and also to economic factors linked to it. These authors also addressed legal issues related to strong reverse logistics, especially in some European countries such as Germany and the Netherlands. The laws in these countries require manufacturers to develop a product reuse policy for the end of the product life cycle.

\section{Importance and application of reverse logistics in retail}

Companies are the main users of natural resources and are also responsible for global economic development (Braga Junior and Rizzo, 2010; Dowlatshahi, 2000). With the changes over time, especially since the Industrial Revolution, organisations began to produce consumer items on a large scale, greatly increasing the amount and diversity of waste generated in urban areas (Motta, 2011; Veiga, 2013). Thus, there was the need to create an alternative way to process such waste.

The scarcity of raw materials and increasing public awareness regarding the preservation of the environment, along with the idea of opposing waste, are some of the factors behind the development of reverse logistics (Fehr et al., 2010). According to Braga Junior et al. (2009), in the grocery retail, reverse logistics can emerge as a new possibility for profit and generate a great image for the company as it assumes the role of an environmentally friendly company. In addition, reverse logistics also assists in the performance of the organisation, leading to recovery of materials that were generated and would be discarded, as well as helping to reduce the environmental and social impacts of waste generated by this sector and incorporating social and economic aspects (Chaves et al., 2014; Santos et al., 2014).

Braga Junior and Rizzo (2010) also explained the importance of reverse logistics in the supermarket sector from the perspective of contributing to the reduction of social and environmental impacts, providing the opportunity to recycle paper, plastic, cardboard, pallets, and other products coming from suppliers to supermarkets, allowing the emergence of a secondary market that generates direct and indirect jobs.

Dowlatshahi (2000) and Rossi and Cullen (2011) suggested that reverse logistics, when applied, can bring economic advantages because the products' original cost is offset by the value of the returned products, and recycled products have a significantly lower value compared with the cost of the original item. In this respect, some German companies use a reverse logistics model to maximise their profits arising from the sale of materials that can 
Table 1. Conversion table (kilograms).

\begin{tabular}{lllrl}
\hline & Abiotic material & Biotic material & Water & Air \\
\hline Plastic & 6.45 & & 294.20 & 3.72 \\
Cardboard & 1.86 & 0.75 & 93.60 & 0.33 \\
\hline
\end{tabular}

Adapted from Ritthoff et al. (2002).

be recycled, thus generating a financial return for the organisation (Reyes and Meade, 2006).

In the United States, the greatest strength of reverse logistics is its link to economic issues. The potential value that can be recovered from the reuse and recycling of products is significant (Kokkinaki et al., 2001). Nationally and internationally, reverse logistics has been present for years in the concepts and business practices, updating itself according to the conditions imposed by the macro and micro environments in which they operate.

\section{Materials and methods}

Whereas the objective of the research was to demonstrate the environmental benefits and the importance of environmental education in the implementation of reverse logistics in the grocery retail, a study was conducted of a supermarket in Sao Paulo, Brazil, in order to measure the volumes of waste (plastic and cardboard) collected by means of reverse logistics.

To achieve this purpose, the method developed by Ritthoff et al. (2002) Wuppertal Institute for analysing environmental advantages was used. This method allows the assessment of environmental changes associated with the extraction of resources from their natural ecosystems. Thus, to supply materials to a system, a greater amount of materials must be previously processed into various environmental components, which can be classified as abiotic, biotic, water, and air (Ritthoff et al., 2002).

The conversion of volumes was based on the study of Ritthoff et al. (2002) Wuppertal Institute. The table of conversion data is represented by Table 1, which highlights values for plastic and cardboard. To obtain the results, the monthly volume of solid waste, generated in kilograms $(\mathrm{kg})$, was multiplied by the corresponding value in Table 1 to get the total volume of materials that are no longer generated in the environment or which were left to pollute.

The values in the abiotic and biotic material columns indicate amounts generated in the environment, while the values in the water and air fields indicate the amount of pollution produced [or reduced] by the practice of reverse logistics. It is important to describe what abiotic and biotic materials are. Abiotic materials are not decomposed in the environment, and biotic undergo a decomposition process. Because of this, only cardboard is considered at the biotic material compartment, as plastic takes over 400 years to decompose in the environment.

It is important to note that studies of material intensity developed at the Ritthoff et al. (2002) Wuppertal Institute are based on energy mixes in Germany and elsewhere in Europe. However, this fact does not preclude the implementation of this methodological tool in Brazil; according to the institute, the quantitative data are very close.

Based on the research problem and the overall goal, a theoretical review of the issues covered in the survey was conducted. Field research was then done to learn about the processes implemented by the researched supermarket; through weekly monitoring, data related to the reverse logistics process research were collected over a period of 6 months and recorded in a spreadsheet. The collected data were then analysed qualitatively and quantitatively, to determine the environmental benefits generated by the process.

The quantitative analysis measured the environmental advantages of the implementation of reverse logistics in the supermarket, facilitating the development of the case study. Qualitative research, characterised as an attempt to produce detailed understanding of the meanings and situational characteristics presented by the interviewees and the cases analysed (Yin, 2003), allowed in-depth observation of the deployment of reverse logistics processes and the environmental education process that was instituted for the supermarket's staff.

\section{Analysis and search results}

The researched supermarket has a sales area of $1300 \mathrm{~m}^{2}$ with 12 checkout lines, and records an average monthly flow 45,000 47,000 people. The consumer base includes mainly high income consumers. However, it also meets the needs of low income consumers, reaching with the sales of the supermarket an average value of US $\$ 23.00$ per consumer. Having a favourable layout for purchasing decisions, it is the only supermarket in the city that offers particular services and differentiated products, such as telephone shopping and a wide range of imported products.

Through environmental education processes and waste separation, reverse logistics was established less than a year ago and became part of the local management strategy. The study began at the same time that the management of reverse logistics practice applied in the company was changed, to a more efficient manner, where solid waste materials, such as plastic and cardboard, began to be separated into bags and by sector (general grocery, cold cuts, butcher, and vegetable garden and fruit).

Before the implementation of reverse logistic in this supermarket, the materials like plastic and cardboard, they were separated at the warehouse and collected by recycling collectors in Exchange for letting the area clean. This way, the retailer was not taking all the advantages obtained by the reverse logistics practices.

The supermarket is divided into four major sectors and all of them store waste that are targeted as the source sector. The amount of cardboard and plastic generated, separated, and used to measure the volume of biotic material, abiotic, water, and air that are no longer polluted by each sector is shown in Table 2 .

The bags are placed in front of each sector, where the workers put the materials on site to reach optimum capacity. They are then sent to the warehouse from the supermarket, where these bags are 
Table 2. Amount of plastic and cardboard generated by the supermarket (kilograms).

\begin{tabular}{|c|c|c|c|c|c|c|c|c|}
\hline & \multicolumn{2}{|c|}{ General grocery } & \multicolumn{2}{|c|}{ Cold cuts } & \multicolumn{2}{|c|}{ Butcher } & \multicolumn{2}{|c|}{ Farmer's market } \\
\hline & Plastic & Cardboard & Plastic & Cardboard & Plastic & Cardboard & Plastic & Cardboard \\
\hline July/14 & 269.00 & 2066.00 & 55.00 & 363.00 & 55.00 & 579.00 & 0 & 542.00 \\
\hline August/14 & 235.00 & 1806.00 & 0 & 317.00 & 0 & 317.00 & 0 & 474.00 \\
\hline September/14 & 301.00 & 2316.00 & 0 & 407.00 & 0 & 650.00 & 0 & 607.00 \\
\hline October/14 & 310.00 & 2389.00 & 0 & 420.00 & 0 & 670.00 & 0 & 626.00 \\
\hline November/14 & 385.00 & 2724.00 & 0 & 561.00 & 0 & 764.00 & 0 & 654.00 \\
\hline December/14 & 274.00 & 2790.00 & 0 & 407.00 & 0 & 784.00 & 56.00 & 792.00 \\
\hline Total & 1774.00 & $14,091.00$ & 55.00 & 2475.00 & 55.00 & 3764.00 & 56.00 & 3695.00 \\
\hline
\end{tabular}

Table 3. Environmental advantages obtained in total by retailer through the reverse logistics (kilograms).

\begin{tabular}{lllrr}
\hline & Abiotic material & Biotic material & Water & Air \\
\hline Plastic & $11,789.00$ & & $537,740.50$ & $6,804.00$ \\
Cardboard & $45,039.00$ & $18,161.00$ & $2,266,524.00$ & $7,869.00$ \\
Total & $56,828.00$ & $18,161.00$ & $2,804,264.50$ & $14,673.00$ \\
\hline
\end{tabular}

Table 4. Environmental advantages obtained by general grocery sector through the reverse logistics (kilograms).

\begin{tabular}{lcrrr}
\hline & Abiotic material & Biotic material & Water & Air \\
\hline Plastic & 7572.00 & & $345,390.00$ & 4370.00 \\
Cardboard & $26,209.00$ & $10,568.00$ & $1,318,917.00$ & 4579.00 \\
Total & $33,781.00$ & $10,568.00$ & $1,664,307.00$ & 8948.00 \\
\hline
\end{tabular}

sent to the chain headquarter by the same truck that makes the distribution of products for sale, and there they are pressed and weighted to be sold. This type of process can allow greater efficiency to the retailer by focusing on volume and processing costs (Braga Junior et al., 2009).

Within 6 months of the implementation of reverse logistics, it was noted that the supermarket eliminated the production of $56,828.00 \mathrm{~kg}$ of abiotic material, which cannot be transformed in the environment over time, and $18,161.00 \mathrm{~kg}$ of biotic materials, which can be transformed into the environment, as shown in Table 3 .

Table 3 also shows that the company eliminated the pollution of $2,788,434.00 \mathrm{~L}$ of water and $14,474.00 \mathrm{~kg}$ of air owing to the practice of reverse logistics, considering the water and air affected by the process of manufacturing of the plastic and cardboard materials.

The relationship of plastic and cardboard with these data is given by the incorrect disposal of these materials on the environment, causing several impacts. The cardboard is composed of many substances, which includes abiotic and biotic materials. Plastic is also composed of many substances, but does not present composition with biotic materials, being composed only for abiotic materials, thereby does not decompose in the environment.

The production of any material generates pollution. Thus, the water and air fields represent how much was left to pollute the water and air in the manufacturing process of plastic and cardboard. So, these data represent what is recovered; not polluting the environment with the adoption of reverse logistics practices.
To observe more precisely the generation of plastic and cardboard in each sector of the supermarket, individual volumes are presented. Table 4 shows the amount of waste generated by the general grocery sector. This sector accounts for all dry areas, encompassing the supermarket's grocery, bakery, bazaar, textiles, and electronics departments (Parente, 2000). The general grocery sector accounts for approximately $60 \%$ in reduction of abiotic material, $58 \%$ of biotic material, $60 \%$ of the eliminated water pollution, and $62 \%$ of the eliminated air pollution. These values are presented in comparison with the total environmental benefits generated by the implementation of reverse logistics in the grocery.

The sheer volume of material generated by this sector is owing to the large volume of products consumed; because of environmental awareness, various industries have increasingly provided environmentally friendly packaging of cardboard and plastic. The involvement of this sector does not stop there. Most employees involved in the process of separation and loading the bags in the trucks are in this sector. This involvement of staff results in environmental education. In the practices of separating and loading waste, employees learn the importance and necessity of proper management of these materials, which contributes to preserve the environment.

Among all sectors, the cold cuts sector generates the least waste (see Table 5). After products are delivered, the cardboard packaging are separated and discarded. The products are cooled only in the plastic packaging, or arranged on the cold shelves for 
Table 5. Environmental advantages obtained by cold cuts sector through the reverse logistics (kilograms).

\begin{tabular}{lllrr}
\hline & Abiotic material & Biotic material & Water & Air \\
\hline Plastic & 1935.00 & & $88,260.00$ & 1116.00 \\
Cardboard & 4603.00 & 1856.00 & $231,660.00$ & 804.00 \\
Total & 6538.00 & 1856.00 & $319,920.00$ & 1920.00 \\
\hline
\end{tabular}

Table 6. Environmental advantages obtained by butcher sector through the reverse logistics (kilograms).

\begin{tabular}{lllrr}
\hline & Abiotic material & Biotic material & Water & Air \\
\hline Plastic & 1612.00 & & $73,550.00$ & 930.00 \\
Cardboard & 7354.00 & 2965.00 & $370,094.40$ & 1285.00 \\
Total & 8966.00 & 2965.00 & $443,644.40$ & 2215.00 \\
\hline
\end{tabular}

Table 7. Environmental advantages obtained by farmer's market sector through the reverse logistics (kilograms).

\begin{tabular}{lcrrr}
\hline & Abiotic material & Biotic material & Water & Air \\
\hline Plastic & 683.00 & & $31,185.00$ & 394.00 \\
Cardboard & 6872.00 & 2771.00 & $345,852.00$ & 1200.00 \\
Total & 7555.00 & 2771.00 & $377,037.00$ & 1594.00 \\
\hline
\end{tabular}

consumption. All chilled products, such as yogurts, are provided in cardboard packaging or coated plastic.

The plastic packing in this sector is taken back by the suppliers, except when it is harmed. Harmed plastic remains in the supermarket to be disposed and once the employees are directly connected with packing selection, it reinforces the environmental education in the sector as well as in other sectors of the company.

The butcher sector ranks second in terms of the amount of waste generated, and thus, also ranks second in obtaining environmental benefits by the grocery in general (Table 6). This is owing to the packaging of goods, not only to the consumption factor. The products come packaged in thicker cardboard boxes. Thus, owing to the necessity of humidity control for these products, and the thickness of the packaging, the butcher sector bags weigh more than those of other sectors, which are thinner and without moisture in their packaging.

The Farmer's Market sector, shown in Table 7, deals with vegetables and fruits in general. Owing to the seasonality of these products, there were some consumption peaks during the research. The increase in consumption was significant in December, when it doubled owing to end of year festivities.

Another relevant fact is that fruit and vegetable packaging is being gradually replaced. Items that previously came in wooden crates now come in plastic boxes, which are returned to suppliers to be reused. However, this type of disposable packaging still occurs with some products, such as carrots, oranges, lettuce, cabbage, potatoes, bananas, and onions, which can be loaded in large amounts. The average weight per box is $25 \mathrm{~kg}$. More sensitive products, such as apples, pears, and grapes, are provided in smaller amounts and smaller packaging of plastic-coated cardboard.

Figure 1 shows the amount of each type of waste reduced during the analysis period, by sector. For best viewing, it was necessary to normalise the $Y$-axis in base 10 logarithms, framing the chart on a smaller scale to render more legible the significant variation between sectors and types of waste. This analysis identifies the importance of each sector within the supermarket, measuring its contribution to reducing the generation of various kinds of waste.

\section{Conclusions}

Reverse logistics is an organisational practice of paramount importance to the environment, contributing to preservation, and reducing the pollution of soil, water, and air. With the implementation and good management of reverse logistics processes, the results are significantly positive, generating profit for the company through the sale of materials, contributing to the environmental awareness of everyone involved in the process, and reducing the environmental impact generated by the disposal of materials in landfills.

Owing to the high turnover of products that occurs in the grocery retail, the amount of solid waste generated is significant; therefore, adopting reverse logistics is essential and can improve the company's image as an environmentally friendly organisation. In the short period of the study ( 6 months), the supermarket significantly reduced the amount of waste it generated.

For each kilogramme of recycled plastic and cardboard, it was possible to avoid generating $2.18 \mathrm{~kg}$ of abiotic materials and $0.75 \mathrm{~kg}$ of biotic material in the environment. Likewise, it was possible to stop contaminating $107.68 \mathrm{~kg}$ of water and $0.56 \mathrm{~kg}$ of air. In total, the supermarket stoped sending to the landfill more than 15 tonne of material per month. Currently, there is only discarded organic waste, which equates to no more than $1 \mathrm{t}$ per month. 


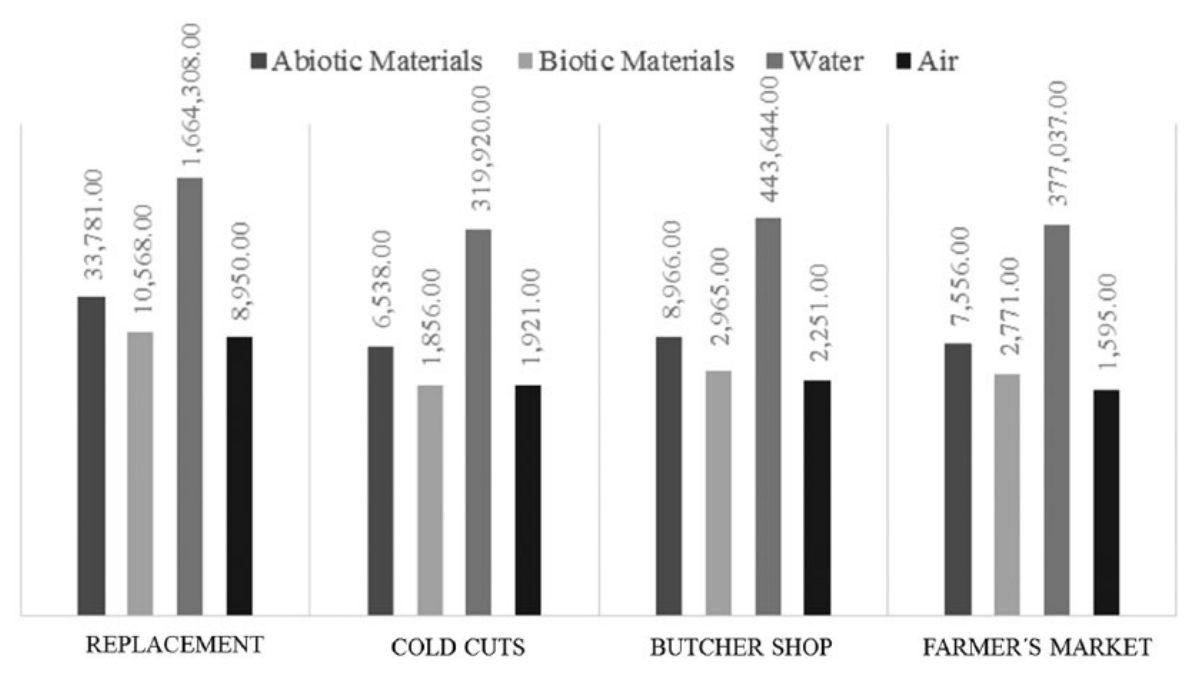

Figure 1. Wastes that are no longer generated, separated by sector.

The management practices identified and presented here can help everyone directly involved in the separation process to become more aware about the importance of reverse logistics practice and its positive impact on the environment, causing everyone involved to adopt new behaviours in the daily lives and new practices to protect the environment, positively impacting their families and living circles.

Reverse logistics can be considered a great ally in the preservation of the environment in general, and is also a great source of environmental education for everyone involved in the process, for managers, and for those who deal directly with the separation of residues.

\section{Declaration of conflicting interests}

The author(s) declared no potential conflicts of interest with respect to the research, authorship, and/or publication of this article.

\section{Funding}

The author(s) received no financial support for the research, authorship, and/or publication of this article.

\section{References}

Ahluwalia PK and Nema AK (2006) Multi-objective reverse logistics model for integrated computer waste management. Waste Management \& Research 24: 514-527.

Bernon M, Rossi S and Cullen J (2011) Retail reverse logistics: A call and grounding framework for research. International Journal of Physical Distribution \& Logistics Management 41: 484-510.

Braga Junior SS and Rizzo MR (2010) Sustentabilidade através do aproveitamento de resíduos: Um estudo dos processos implantados por um supermercado de médio porte [Sustainability through the utilization of waste: A study of procedures implemented in a midsize supermarket]. Revista Brasileira de Engenharia de Biossistemas 4: 108-125.

Braga Junior SS and Santos RBME (2015) Environmental gains from the practice of reverse logistics retail supermarket. Espacios (Caracas) 36: 14.

Braga Junior SSB, Merlo EM and Nagano MS (2009) Um estudo comparativo das práticas de logística reversa no varejo de médio porte [A comparative study of reverse logistics practices in the midsize retail]. Revista da Micro e Pequena Empresa 3: 64-81.

BRASIL. PNRS - Política Nacional de Resíduos Sólidos [Nacional Policy in Solid Waste]. Subemenda Substitutiva Global de Plenário ao Projeto de Lei $\mathrm{n}^{\circ}$ 203, de 1991. Available at: http://www.revistasustentabilidade. com.br/reciclagem/reciclagem/documentosinteressante/relatorio-finalda-politica-de-residuos (accessed 28 March 2014).

Chaves GDLD, dos Santos JL and Rocha SMS (2014) The challenges for solid waste management in accordance with Agenda 21: A Brazilian case review. Waste Management \& Research 32: 19-31.

Daher CE, Silva EPDLS and Fonseca AP (2006) Logística reversa: oportunidade para redução de custos através do gerenciamento da cadeia integrada de valor [Reverse logistics: Opportunities to reduce costs through the management the integrated chain of value]. Brazilian Business Review 3. Available at: http://www.bbronline.com.br/artigos. asp?sessao $=$ ready\&cod_artigo $=281$ (accessed 15 March 2014).

Dias SR (2003) Gestão de marketing [Marketing Management]. São Paulo: Saraiva.

Dowlatshahi S (2000) Developing a theory of reverse logistics. Interfaces 30: $143-155$.

Fehr M (2014) The management challenge for household waste in emerging economies like Brazil: Realistic source separation and activation of reverse logistics. Waste Management \& Research 32: 32-39.

Fehr M, de Castro MSV and dos Reis Calçado M (2010) Condominium waste management by private initiative: A report of a 10-year project in Brazil. Waste Management \& Research 28: 309-314.

Gonçalves P (2003) A reciclagem integradora dos aspectos ambientais, sociais e econômicos [The integrating recycling of environmental, social and economic aspects]. Rio de Janeiro/RJ, Brazil: Rio de Janeiro/RJ, Brazil: FASE, DP\&A.

Hazen BT, Huscroft J, Hall DJ, et al. (2014) Reverse logistics information system success and the effect of motivation. International Journal of Physical Distribution \& Logistics Management 44: 201-220.

Horvath PA, Autry CW and Wilcox WE (2005) Liquidity implications of reverse logistics for retailers: A Markov chain approach. Journal of Retailing 81: 191-203.

John VM (2000) Reciclagem de resíduos na construção civil: Contribuição à metodologia de pesquisa e desenvolvimento [Recycling of waste in construction: Contribution to research and development methodology]. Tese de Doutorado. Tese Livre Docência, Universidade de São Paulo. São Paulo: Escola Politécnica/USP.

Kokkinaki AI, Dekker R, de Koster R, et al. (2001) From e-trash to e-treasure: How value can be created by the new e-business models for reverse logistics (No. EI 2000-32/A). Econometric Institute Research Papers.

Leite PR (2003) Logística reversa [Reverse logistics]. São Paulo: Pearson.

Mano EB, Pacheco ÉBAV and Bonelli CMC (2005) Meio ambiente, poluição e reciclagem [Environment, pollution and recycling]. São Paulo/SP, Brazil: Edgard Blücher.

Marchi CMDF (2011) Cenário mundial dos resíduos sólidos e o comportamento corporativo brasileiro frente à logística reversa [World scenario fopr solid waste and Brazilian corporate behavior forward to reverse logistics]. Perspectivas em Gestão \& Conhecimento 1: $118-135$. 
Motta WH (2011) Logística Reversa e a Reciclagem de Embalagens no Brasil. [Reverse Logistics and Packaging Recycling in Brazil]. VII Congresso Nacional de Excelência em Gestão, 12, 13 August 2011, pp.5-9. Available at: http://www.excelenciaemgestao.org/pt/edicoesanteriores/vii-cneg/anais.aspx (accessed 28 March 2014).

Parente J (2000) Varejo no Brasil: Gestão e estratégia [Retail in Brazil: Management and strategy]. São Paulo: Editora Atlas.

Parente J and Gelman JJ (2006) Varejo e responsabilidade social [Retail and social responsibility]. Porto Alegre: Bookman.

Pinto TDP (1999) Metodologia para a gestão diferenciada de resíduos sólidos da construção urbana [Methodology for differentiated management of solid waste from urban construction]. Unpublished doctoral dissertation, Universidade de São Paulo, São Paulo.

Reyes PM and Meade LM (2006) Improving reverse supply chain operational performance: A transshipment application study for not-for-profit organizations. Journal of Supply Chain Management 42: 38-48.

Ritthoff M, Rohn H and Liedtke C (2002) Calculating MIPS: Resource productivity of products and services (No. 27e). Wuppertal Spezial, Wuppertal Institut für Klima, Umwelt und Energie.
Rogers DS and Tibben-Lembke RS (1999) Going backwards: Reverse logistics trends and practices (Vol. 2). Pittsburgh, PA: Reverse Logistics Executive Council.

Saab WGL and Gimenez LCP (2000) Aspectos atuais do varejo de alimentos no mundo e no Brasil [Current aspects of food retail in the world and in Brazil]. BNDES Setorial 11: 101-122.

Santos RBM, Braga Junior SS, Silva D, et al. (2014) Analysis of the economic and environmental benefits through the reverse logistics for retail. American Journal of Environmental Protection 3: $138-143$.

Senhoras EM (2003) O varejo supermercadista sob perspectiva [The retail supermarket in perspective]. Read-Revista Eletrônica de Administração 9(33): mai-jun 2003.

Veiga MM (2013) Analysis of efficiency of waste reverse logistics for recycling. Waste Management \& Research 31: 26-34.

Weitz BA and Levy M (2000) Administração de varejo [Retail Management]. São Paulo: Atlas.

Yin RK (2003) Estudo de Caso: Planejamento e Métodos [Case study: Design and methods]. Porto Alegre: Bookman Editora. 